Studi Kasus

\title{
Pengaruh Kombinasi Perawatan Luka dan Latihan Range of Motion Ekstermitas Bawah terhadap Penyembuhan Ulkus Diabetik pada Pasien Diabetes Mellitus
}

\author{
Maya Lailasari ${ }^{1}$, Arief Yanto $^{2}$, Akhmad Mustofa $^{3}$ \\ 1 Mahasiswa Program Studi D3 Keperawatan, Fakultas Ilmu Keperawatan dan Kesehatan, Universitas \\ Muhammadiyah Semarang \\ 2,3 Dosen Program Studi Keperawatan, Fakultas Ilmu Keperawatan dan Kesehatan, Universitas Muhammadiyah \\ Semarang
}

\section{Informasi Artikel}

Riwayat Artikel:

- Submit: 30 Oktober 2021

- Diterima: 22 Desember 2021

- Terbit: 29 Januari 2022

Kata kunci:

Granulasi; ulkus diabetikum; vaskularisasi; wound care

\begin{abstract}
Abstrak
Pasien DM beresiko terjadi kerusakan pada pembuluh darah. Ulkus diabetik merupakan salah satu gangguan pada ekstermitas bawah dari komplikasi makrovaskuler yang dapat berakhir dengan amputasi. Perawatan luka dan latihan range of motion (ROM) ekstermitas bawah mampu menyembuhkan ulkus diabetik. Studi kasus ini bertujuan untuk mengetahui pengaruh kombinasi perawatan luka dan latihan range of motion (ROM) ekstermitas bawah untuk penyembuhan ulkus diabetik pada pasien diabetes mellitus. Studi kasus ini menggunakan desain studi deskriptif dengan pendekatan proses asuhan keperawatan. Subyek studi kasus adalah pasien DM yang terdapat ulkus diabetik. Subjek studi didapatkan melalui tehnik purposive sampling. Hasil studi kasus menunjukan pengaruh tindakan perawatan luka dan ROM terhadap proses granulasi luka ulkus diabetikum. Hasil observasi ulkus diabetikum menunjukkan penurunan skor dari 32 pada hari pertama menjadi 27 pada observasi hari kedua. Pada hari ketiga pengukuran diketahui skor 20 turun menjadi 18 pada observasi hari berikutnya. Berdasarkan hasil studi kasus ini dapat disimpulkan bahwa terdapat pengaruh kombinasi tindakan perawatan luka dan latihan range of motion (ROM) ekstermitas bawah terhadap penyembuhan ulkus diabetik pada pasien diabetes melitus.
\end{abstract}

\section{PENDAHULUAN}

Diabetes Mellitus (DM) adalah sekumpulan gangguan metabolisme yang ditandai dengan peningkatan kadar glukosa darah (hiperglikemi) akibat kerusakan pada sekresi insulin, kerja insulin atau keduanya (Smeltzer, C. 2013). Berdasarkan data yang diperoleh dari International Diabetes Federation (IDF), angka penderita diabetes mellitus di dunia tercatat sebesar 425 juta orang pada tahun 2017, Diperkirakan penderita diabetes mellitus terus meningkat menjadi 629 juta orang pada tahun 2030-2045. Indonesia termasuk Negara yang mewakili orang dewasa yang menderita diabetes mellitus sekitar usia 2079 (Cho, dkk. 2017).

Komplikasi yang sering dialami oleh penderita DM adalah luka pada kaki yang disebut dengan ulkus diabetik. Ulkus

Corresponding author:

Maya Lailasari

mayalailasari163@gmail.com

Holistic Nursing Care Approach, Vol 2 No 1, Januari 2022

e-ISSN: 2808-2095

DOI: https://doi.org/10.26714/hnca.v2i1.8477 
Maya Lailasari - Pengaruh Kombinasi Perawatan Luka dan Latihan Range of Motion Ekstermitas Bawah terhadap

Penyembuhan Ulkus Diabetik pada Pasien Diabetes Mellitus

diabetik terjadi karena berkurangnya aliran darah ke kaki yang berlanjut menjadi atherosclerosis sehingga suplai darah ke kaki mengalami gangguan. Penderita diabetes mellitus dengan adanya ulkus diabetik perlu dilakukan penanganan lebih serius (Wijaya, dkk 2013).

Perawatan luka merupakan tindakan keperawatan dengan tujuan mencegah infeksi (masuk melalui luka) dan mempercepat proses penyembuhan ulkus. Dalam perawatan luka ada tiga hal yang perlu diperhatikan yaitu mencuci area luka, mengambil jaringan mati atau autolitik dan memilih topikal ataupun dressing yang tepat (Wijaya, dkk 2013). Range Of Motion (ROM) eksternitas bawah adalah kegiatan yang dilakukan oleh penderita diabetes mellitus untuk membantu melancarkan peredaran darah di bagian kaki, memperbaiki sirkulasi darah, meningkatkan kekuatan otot betis dan paha, serta mengatasi keterbatasan gerak sendi (Herliawati, 2019). Tindakan keperawatan untuk penanganan masalah ulkus diabetik pada pasien diabetes dengan perawatan luka dan latihan range of motion (ROM) ekstermitas bawah.

Perawatan luka secara konvensional dengan menggunakan $\mathrm{NaCl}$ dan metronidazole yang baik dan benar dapat pengaruh dalam mempercepat penyembuhan luka kaki diabetik (selama 3 minggu luka membaik) daripada hanya menggunakan $\mathrm{NaCl}$ saja (selama 6 minggu luka baru terjadi pemulihan) (Mulyono, dkk. 2012). Latihan Range Of Motion (ROM) ekstermitas bawah dapat mempengaruhi penyembuhan ulkus diabetik pada pasien DM (Nugroho, dkk. 2018). Studi kasus ini bertujuan untuk mengetahui pengaruh perawatan luka dan latihan range of motion (ROM) untuk penyembuhan ulkus diabetik pada pasien diabetes melitus.

\section{METODE}

Studi kasus ini menggunakan desain studi deskriptif. Pendekatan yang digunakan dalam studi ini adalah pendekatan asuhan keperawatan yang meliputi dari pengkajian, diagnosa keperawatan, intervensi atau perencanaan, implementasi atau pelaksanaan, dan juga evaluasi. Studi kasus ini menerapkan Tindakan perawatan luka dan ROM pada pasien DM, dan melakukan observasi dan pengukuran pada kondisi luka ulkus diabetikum.

Subjek studi kasus ini adalah pasien yang menderita Diabetes Mellitus dengan kriteria inklusi antara lain adanya ulkus pada ekstermitas bawah, berusia 20 sampai lebih dari 50 tahun, tingkat kesadaran composmentis, mampu berkomunikasi secara verbal serta kooperatif, bersedia menjadi responden, Subjek studi berjumlah 2 orang pasien dengan pengambilan subjek studi menggunakan tehnik purposive sampling.

Perlakuan yang dilakukan pada subjek studi kasus adalah perawatan luka dan latihan range of motion (ROM) ekstermitas bawah. Proses pelaksanaan studi kasus diawali dengan dengan meminta surat izin, memilih pasien yang sudah ditetapkan sesuai kriteria, Memberikan penjelasan kepada calon subjek studi kasus dan meminta persetujuan, menjelaskan tujuan dan prosedur tindakan yang akan dilakukan. Pelaksanaan Tindakan keperawatan dilakukan sebanyak 3 kali perawatan luka dan latihan range of motion (ROM) ekstermitas bawah setiap hari selama satu minggu. Evaluasi terhadap kondisi luka dilakukan setiap pelaksanaan Tindakan perawatan luka. 
Studi kasus dilakukan pada penderita diabetes mellitus dengan ulkus diabetik di Desa Kangkung Kecamatan Mranggen pengelolaan pasien dilakukan selama 1 minggu dengan frekuensi pelaksanaan Tindakan sebanyak 3 kali perawatan luka dan latihan range of motion (ROM) ekstermitas bawah setiap hari. Studi kasus ini dilakukan pada tangaal 1-7 maret 2021.

Instrument yang digunakan dalam studi kasus ini adalah lembar observasi ulkus diabetik Skala BWAT (Bates-Jensen Wound Assesment Tool). Pengukuran terhadap kondisi luka pasien dilakukan sebanyak 3 kali dalam 1 minggu. Evaluasi terhadap kondisi luka pasien dilakukan oleh penulis sendiri. Data hasil pengukuran dan dokumentasi dikelola oleh penulis dan tidak mencantumkan identitas pasien. Data hasil pengukuran dilakukan analisis dengan membandingkan skor hasil observasi selama pelakssanaan Tindakan keperawatan kepada pasien. Data hasil observasi telah mendapatkan ijin dari pasien untuk dipublikasikan

\section{HASIL}

Hasil studi kasus ini menggambarkan pengelolaan kasus pada dua pasien diabetes mellitus yang mengalami ulkus diabetik. Tindakan perawatan luka yang dilakukan 3 kali selama satu minggu dan latihan range of motion (ROM) ekstermitas bawah yang akan dilakukan setiap hari selama satu minggu dan diobservasi setiap perawatan luka dilakukan.

\section{Pengkajian}

Pengkajian ini dilakukan pada tanggal 1 Maret 2021 pada dua responden yang menderita diabetes melitus dengan adanya ulkus diabetik di Desa Kangkung Kecamatan Mranggen.

Hasil pengkajian menunjukkan bahwa subjek studi kasus terdapat ulkus diabetikum. Subjek studi kasus memiliki keluhan terdapat luka di bagian ekstermitas bawah tepatnya di telapak kaki bagian kanan dan ibu jari kaki sebelah kiri , Subyek studi kasus mengatakan lukanya semakin melebar.

Subjek studi kasus memiliki Riwayat penyakit Diabetes Mellitus. Hasil pemeriksaan fisik didapatkan data bahwa subjek studi kasus memiliki luka pada ekstremitas bawah dengan karakteristik luka: warna luka pucat, tepi luka ada yang menyatu dengan dasar luka dan ada yang tidak menyatu dengan dasar luka, ada goa, ada jaringan nekrosis, terdapat eksudat kental ataupun encer dengan warna kekuningan, dengan bau, Warna kulit sekitar luka adalah hitam kecoklatan ataupun pucat, terdapat edema sekitar luka, tidak ada jaringan granulasi.

\section{Diagnosa keperawatan}

Diagnosa keperawatan utama pada subjek studi kasus adalah Gangguan integritas kulit berhubungan dengan perubahan sirkulasi perifer. Diagnosa keperawatan tersebut dirumuskan berdasarkan karakteristik mayor yaitu terdapat kerusakan jaringan atau lapisan kulit. Dan berdasarkan karakteristik minor yaitu nyeri.

\section{Rencana keperawatan}

Rencana tindakan keperawatan yang dirumuskan untuk subjek studi kasus antara lain: monitor vital sign, catat karakteristik luka secara komprehensif, lakukan perawatan luka dan berikan latihan range of motion (ROM) ekstermitas bawah.

\section{Implementasi keperawatan}

Pelaksanaan perawatan luka dan latihan range of motion (ROM) ekstermitas bawah untuk penyembuhan ulkus diabetik dilakukan pada Subyek studi kasus. Tindakan perawatan luka dilakukan kepada subjek studi kasus pada setiap pagi selama 30 menit. Pelaksanaan tindakan perawatan luka dengan menggunakan kompres metronidazole. Setelah perawatan luka selesai, kemudian berikan latihan range of motion (ROM) ekstermitas bawah terutama dengan gerakan dorsofleksi dan 
Maya Lailasari - Pengaruh Kombinasi Perawatan Luka dan Latihan Range of Motion Ekstermitas Bawah terhadap Penyembuhan Ulkus Diabetik pada Pasien Diabetes Mellitus

plantarfleksi. Tindakan ROM dilakukan bersamaan pada kaki kiri dan kanan secara bergantian dan diulangi sebanyak 10 kali. Untuk waktu pelaksanaan yaitu 3 kali perawatan luka dan latihan range of motion (ROM) setiap hari selama satu minggu. Dan didapatkan respon klien setelah dilakukan tindakan perawatan luka dan latihan range of motion (ROM) ekstermitas bawah yaitu luka lebih bersih dan senang karena ada yang mau merawat lukanya.

\section{Evaluasi keperawatan}

Evaluasi untuk diagnosa gangguan integritas kulit, setelah diberikan tindakan

Tabel 1

Hasil observasi ulkus diabetikum pasien diabetes melitus skala BWAT (Bates-Jansen Wound

\begin{tabular}{|c|c|c|c|c|}
\hline $\begin{array}{c}\text { Subyek } \\
\text { studi }\end{array}$ & Indikator & Hari 1 & Hari 2 & Hari 3 \\
\hline \multirow[t]{6}{*}{ Pasien 1} & Ukuran & $\begin{array}{l}\text { Panjang : } 13 \mathrm{~cm} \\
\text { Lebar: } 6 \mathrm{~cm}\end{array}$ & $\begin{array}{l}\text { Panjang: } 13 \mathrm{~cm} \\
\text { Lebar: } 5 \mathrm{~cm}\end{array}$ & $\begin{array}{l}\text { Panjang: } 13 \mathrm{~cm} \\
\text { Lebar: } 4,6 \mathrm{~cm}\end{array}$ \\
\hline & Eritema & $\begin{array}{ll}\text { Laserasi } & \text { lapisan } \\
\text { epidermis dan dermis, } \\
\text { warna luka merah } \\
\text { kekuningan }\end{array}$ & $\begin{array}{l}\text { Eritema atau } \\
\text { kemerahan }\end{array}$ & $\begin{array}{ll}\text { Eritema atau } \\
\text { kemerahan }\end{array}$ \\
\hline & Tepi luka & $\begin{array}{l}\text { Tepi luka jelas ada } \\
\text { yang menyatu dengan } \\
\text { dasar luka dan juga ada } \\
\text { yang tidak menyatu } \\
\text { dengan dasar luka } \\
\text { terutama dibagian } \\
\text { dekat goa }\end{array}$ & $\begin{array}{l}\text { Tepi luka jelas ada } \\
\text { yang menyatu dengan } \\
\text { dasar luka dan juga ada } \\
\text { yang tidak menyatu } \\
\text { dengan dasar luka } \\
\text { terutama dibagian } \\
\text { dekat goa }\end{array}$ & $\begin{array}{l}\text { Tepi luka jelas ada } \\
\text { yang menyatu dengan } \\
\text { dasar luka dan juga ada } \\
\text { yang tidak menyatu } \\
\text { dengan dasar luka } \\
\text { terutama dibagian } \\
\text { dekat goa }\end{array}$ \\
\hline & Kedalaman & Kedalaman gua $<2 \mathrm{~cm}$ & Kedalaman gua $<2 \mathrm{~cm}$ & Kedalaman gua $<2 \mathrm{~cm}$ \\
\hline & $\begin{array}{l}\text { Tipe } \\
\text { jaringan } \\
\text { nekrotik }\end{array}$ & 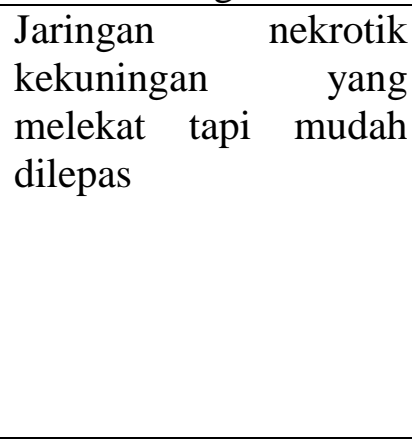 & $\begin{array}{lr}\text { Jaringan nekrotik } \\
\text { adaya yang berwarna } \\
\text { putih atau abu-abu } \\
\text { jaringan tidak dapat } \\
\text { teramati dan atau } \\
\text { jaringan nekrotik } \\
\text { kekuningan yang } \\
\text { melekat tapi mudah } \\
\text { dilepas }\end{array}$ & $\begin{array}{l}\text { Tidak ada jaringan } \\
\text { nekrotik }\end{array}$ \\
\hline & $\begin{array}{l}\text { Jumlah } \\
\text { jaringan } \\
\text { nekrotik }\end{array}$ & $\begin{array}{l}\text { Jumlah jaringan } \\
\text { nekrotik }<25 \%\end{array}$ & $\begin{array}{l}\text { Jumlah } \quad \text { jaringan } \\
\text { nekrotik }<25 \%\end{array}$ & $\begin{array}{l}\text { Tidak ada jaringan } \\
\text { nekrotik }\end{array}$ \\
\hline
\end{tabular}

keperawatan dengan 3 kali perawatan luka dan latihan range of motion (ROM) ekstermitas bawah setiap hari selama 1 minggu.

Evaluasi proses penyembuhan luka dilakukan dengan menggunakan lembar observasi ulkus diabetikum skala BWAT (Bates-Jansen Wound Assement Tool). Hasil observasi luka ulkus diabetikum pada subjek studi kasus disajikan dalam Tabel 1.

\section{Assement Tool)}


Maya Lailasari - Pengaruh Kombinasi Perawatan Luka dan Latihan Range of Motion Ekstermitas Bawah terhadap Penyembuhan Ulkus Diabetik pada Pasien Diabetes Mellitus

\begin{tabular}{|c|c|c|c|c|}
\hline $\begin{array}{l}\text { Subyek } \\
\text { studi }\end{array}$ & Indikator & Hari 1 & Hari 2 & Hari 3 \\
\hline & $\begin{array}{l}\text { Tipe } \\
\text { eksudat }\end{array}$ & $\begin{array}{l}\text { Tipe eksudat ada yang } \\
\text { encer ada juga yang } \\
\text { kental, } \\
\text { kekuningan dengan bau }\end{array}$ & $\begin{array}{l}\text { Tipe eksudat encer, } \\
\text { warna kekuningan dan } \\
\text { berbau }\end{array}$ & $\begin{array}{l}\text { Tipe eksudat encer, } \\
\text { warna kekuningan dan } \\
\text { berbau }\end{array}$ \\
\hline & $\begin{array}{l}\text { Jumlah } \\
\text { eksudat }\end{array}$ & $\begin{array}{l}\text { Permukaan luka moist, } \\
\text { eksudat membasahi < } \\
25 \% \text { balutan }\end{array}$ & $\begin{array}{l}\text { Permukaan luka moist, } \\
\text { eksudat membasahi } \\
25 \% \text { balutan }\end{array}$ & $\begin{array}{l}\text { Permukaan luka moist, } \\
\text { eksudat membasahi } \\
25 \% \text { balutan }\end{array}$ \\
\hline & $\begin{array}{l}\text { Warna } \\
\text { kulit } \\
\text { sekitar luka }\end{array}$ & $\begin{array}{ll}\text { Hitam } & \text { atau } \\
\text { hiperpigmentasi }\end{array}$ & $\begin{array}{ll}\text { Hitam } & \text { atau } \\
\text { hiperpigmentasi }\end{array}$ & $\begin{array}{ll}\text { Hitam atau } & \text { atperpigmentasi }\end{array}$ \\
\hline & Edema & Edema di sekitar luka & Edema disekitar luka & $\begin{array}{ll}\text { Tidak ada edema } \\
\text { disekitar luka }\end{array}$ \\
\hline & $\begin{array}{l}\text { Jaring } \\
\text { granu }\end{array}$ & $\begin{array}{l}\text { Tidak ada jaringan } \\
\text { granulasi }\end{array}$ & $\begin{array}{l}\text { Pink, dan atau pucat, } \\
\text { merah kehitaman dan } \\
\text { atau luka }<25 \% \text { terisi } \\
\text { granulasi }\end{array}$ & $\begin{array}{l}\text { Pink, dan atau pucat, } \\
\text { merah kehitaman dan } \\
\text { atau luka }<25 \% \text { terisi } \\
\text { granulasi }\end{array}$ \\
\hline Pasien 2 & Uku & $\begin{array}{l}\text { Panjang }: 1,3 \mathrm{~cm} \\
\text { Lebar: } 1 \mathrm{~cm}\end{array}$ & $\begin{array}{l}\text { Panjang: } 1 \mathrm{~cm} \\
\text { Lebar: } 0,8 \mathrm{~cm}\end{array}$ & $\begin{array}{l}\text { Panjang: } 1 \mathrm{~cm} \\
\text { Lebar: } 0,8 \mathrm{~cm}\end{array}$ \\
\hline & Eritema & $\begin{array}{lr}\text { Laserasi } & \text { lapisan } \\
\text { epidermis dan dermis, } \\
\text { warna luka merah } \\
\text { kekuningan }\end{array}$ & $\begin{array}{l}\text { Eritema atau } \\
\text { kemerahan }\end{array}$ & $\begin{array}{l}\text { Eritema } \\
\text { kemerahan }\end{array}$ \\
\hline & Tepi luka & $\begin{array}{l}\text { Jelas tidak menyatu } \\
\text { dengan dasar luka }\end{array}$ & $\begin{array}{l}\text { Batas tepi terlihat, } \\
\text { menyatu dengan dasar } \\
\text { luka }\end{array}$ & $\begin{array}{l}\text { Batas tepi terlihat, } \\
\text { menyatu dengan dasar } \\
\text { luka }\end{array}$ \\
\hline & Kedalaman & Tidak ada goa & Tidak ada goa & Tidak ada goa \\
\hline & $\begin{array}{l}\text { Tipe } \\
\text { jaringan } \\
\text { nekrotik }\end{array}$ & $\begin{array}{l}\text { Tidak ada jaringan } \\
\text { nekrotik }\end{array}$ & $\begin{array}{l}\text { Tidak ada jaringan } \\
\text { nekrotik }\end{array}$ & $\begin{array}{l}\text { Tidak ada jaringan } \\
\text { nekrotik }\end{array}$ \\
\hline & $\begin{array}{l}\text { Jumlah } \\
\text { jaringan } \\
\text { nekrotik }\end{array}$ & $\begin{array}{l}\text { Tidak ada jaringan } \\
\text { nekrotik }\end{array}$ & $\begin{array}{l}\text { Tidak ada jaringan } \\
\text { nekrotik }\end{array}$ & $\begin{array}{l}\text { Tidak ada jaringan } \\
\text { nekrotik }\end{array}$ \\
\hline & $\begin{array}{l}\text { Tipe } \\
\text { eksudat }\end{array}$ & Tidak ada eksudat & Tidak ada eksudat & Tidak ada eksudat \\
\hline & $\begin{array}{l}\text { Jumlah } \\
\text { eksudat }\end{array}$ & Tidak ada, luka kering & Tidak ada, luka kering & Tidak ada, luka kering \\
\hline & $\begin{array}{l}\text { Warna } \\
\text { kulit } \\
\text { sekitar luka }\end{array}$ & $\begin{array}{lll}\text { Warna } & \text { sekitar luka } \\
\text { pucat } & & \end{array}$ & $\begin{array}{l}\text { Merah terang jika di } \\
\text { sentuh }\end{array}$ & $\begin{array}{l}\text { Merah terang jika } \\
\text { disentuh }\end{array}$ \\
\hline & Edema & $\begin{array}{l}\text { Tidak edema sekitar } \\
\text { luka }\end{array}$ & $\begin{array}{l}\text { Tidak ada edema } \\
\text { sekitar luka }\end{array}$ & $\begin{array}{l}\text { Tidak ada edema } \\
\text { sekitar luka }\end{array}$ \\
\hline & $\begin{array}{l}\text { aringan } \\
\text { ranulasi }\end{array}$ & $\begin{array}{l}\text { Tidak ada jaringan } \\
\text { granulasi }\end{array}$ & $\begin{array}{l}\text { Tidak ada jaringan } \\
\text { granulasi }\end{array}$ & $\begin{array}{l}\text { Tidak ada jaringan } \\
\text { granulasi }\end{array}$ \\
\hline
\end{tabular}


Maya Lailasari - Pengaruh Kombinasi Perawatan Luka dan Latihan Range of Motion Ekstermitas Bawah terhadap Penyembuhan Ulkus Diabetik pada Pasien Diabetes Mellitus

Evaluasi kondisi luka juga dilakukan dengan mengamati secara visual kondisi luka yang dialami oleh subjek studi kasus. Kondisi visual luka disajikan dalam Tabel 2.

Tabel 2

Hasil observasi visual luka ulkus diabetikum pasien diabetes melitus

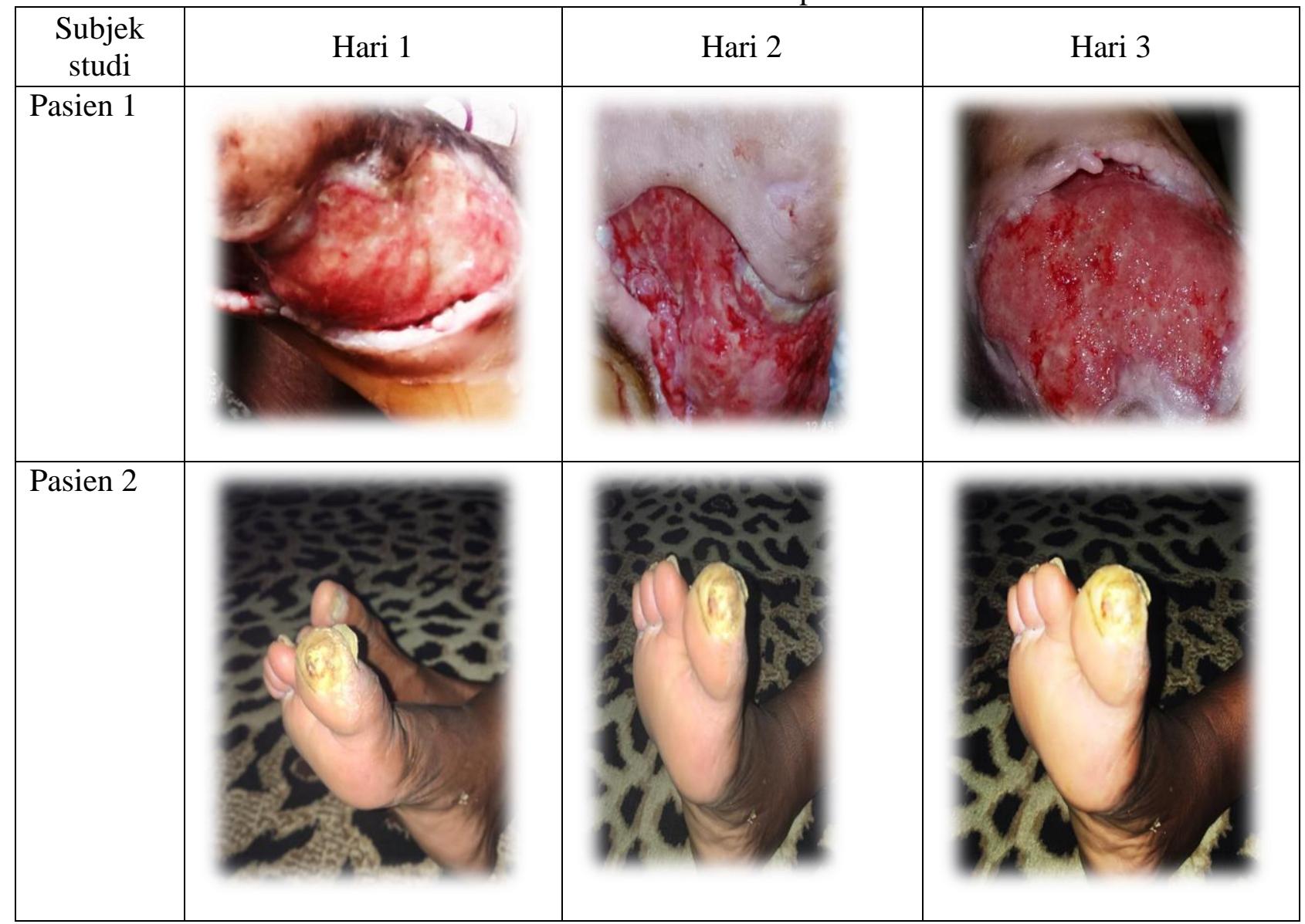

\section{PEMBAHASAN}

Hasil studi kasus ini menunjukkan bahwa subjek studi kasus terdapat ulkus diabetikum. Subjek studi kasus memiliki keluhan terdapat luka di bagian ekstermitas bawah tepatnya di telapak kaki bagian kanan dan ibu jari kaki sebelah kiri. Faktor utama penyebab timbulnya ulkus diabetikum pada penderita diabetes mellitus dikarenakan adanya kenaikan kadar gula didalam darah, sehingga akan menjadi penyebab terganggunya neuropati dan pembuluh darah. Neuropati, baik neuropati sensorik maupun motorik akan mengakibatkan berbagai perubahan pada kulit dan otot yang kemudian akan menyebabkan terjadinya perubahan distribusi tekanan pada telapak kaki dan selanjutnya akan mempermudah terjadinya ulkus pada penderita diabetes mellitus (Wijaya, dkk 2013).

Pengkajian merupakan langkah utama dari proses keperawatan yaitu dimana perawat menerapkan pengetahuan dan pengalaman untuk mengumpulkan data pada subyek studi kasus. Pengumpulan data yang akurat dan sistematis tentang kebutuhan subyek studi kasus dapat meningkatkan efektivitas asuhan keperawatan yang diberikan (Wijaya, dkk. 2013).

Pengkajian yang dilakukan pada subyek studi kasus pada tanggal 1 maret 2021 yaitu dengan anamnesa atau wawancara secara langsung pada pasien, pemeriksaan fisik, 
pemeriksaan penunjang. Dari keseluruhan data tersebut maka penulis mendapatkan data fokus sebagai berikut : saat dilakukan pengkajian pada subyek studi kasus pertama yaitu pada Ny.M sebagian balutan dikasa terdapat rembesan darah dan pus. Karakteristik luka nampak agak kotor, keluar bau tidak sedap dari luka. Luka terkesan berwarna merah kekuningan, terdapat pus, bagian tepi luka berwarna hitam kecoklatan, panjang luka yaitu $13 \mathrm{~cm}$ ,lebar $6 \mathrm{~cm}$, kedalaman $2 \mathrm{~cm}$ dibagian goa.Sedangkan pengkajian yang dilakukan pada subyek studi kasus kedua yaitu Ny.S lukanya dibalut. kondisi luka tidak basah, luka nampak kotor, kulit sekitar luka kering, luka terkesan berwarna merah pucat, panjang luka $1,3 \mathrm{~cm}$, lebar $1 \mathrm{~cm}$.

Diagnosa keperawatan merupakan proses menganalisis data subyektif dan obyektif yang telah diperoleh pada tahap pengkajian untuk menegakkan masalah keperawatan sehingga menjadi diagnosa keperawatan. Diagnosa keperawatan melibatkan bagaimana cara berfikir kompleks tentang data yang didapatkan pada pengkajian yang dilakukan.

Diagnosa keperawatan utama pada subjek studi kasus tersebut dengan tinjauan teori yang ada adalah Gangguan integritas kulit berhubungan dengan perubahan sirkulasi perifer. Diagnosa keperawatan tersebut dirumuskan berdasarkan karakteristik mayor yaitu terdapat kerusakan jaringan atau lapisan kulit, gangguan sensasi. Dan berdasarkan karakteristik minor yaitu nyeri, perdarahan, edema.(Tim Pokja SDKI DPP PPNI, 2016).

Kerusakan integritas kulit tersebut terjadi dikarenakan kerusakan sel beta yang menyebabkan produksi insulin berkurang dan mengakibatkan terjadinya peningkatan konsentrasi glukosa yang disertai mucus, gula darah meningkat, darah menjadi pekat, dan mengakibatkan terjadinya kerusakan pada sistem vaskuler, penurunan aliran darah menjadikan gangguan penyembuhan luka pada ulkus (Smeltzer, C. 2013). kerusakan integritas kulit merupakan salah satu masalah keperawatan pada penderita diabtes mellitus, dimana terdapat adanya luka terbuka yang menyebabkan gangguan permukaan kulit dan kerusakan lapisan kulit (Nurarif, dkk. 2015).

Penulis memperioritaskan masalah utama keperawatan kerusakan integritas kulit karena jika tidak ditangani akan memperluas kerusakan jaringan kulit dan akan menyebabkan komplikasi yang lain seperti penyebaran infeksi. Dan yang terjadi pada subyek studi kasus yaitu mengalami kerusakan integritas kulit terutama dibagian epidermis dan dermis.

Rencana tindakan keperawatan yang dirumuskan untuk subjek studi kasus antara lain: monitor vital sign, catat karakteristik luka secara komprehensif, lakukan perawatan luka dan berikan latihan range of motion (ROM) ekstermitas bawah. Penderita diabetes mellitus dengan adanya ulkus diabetik perlu dilakukan perawatan luka dengan baik, karena Perawatan luka ini merupakan tindakan keperawatan dengan tujuan mencegah infeksi dan mempercepat proses penyembuhan ulkus, bila ulkus diabetik tidak segera dilakukan perawatan dengan baik, maka akan terjadi amputasi pada ekstermitas bawah (Minarningtyas, dkk. 2014).

Berdasarkan hal tersebut, maka perlu juga dilakukan tindakan keperawatan untuk mempercepat penyembuhan ulkus dengan meningkatkan sirkulasi ke area ulkus dengan latihan range of motion (ROM) ekstermitas bawah (Nugroho, dkk. 2018). Range Of Motion (ROM) eksternitas bawah ini merupakan salah satu kegiatan yang dilakukan oleh penderita diabetes mellitus untuk mencegah bahkan membantu melancarkan peredaran darah di bagian kaki, memperbaiki sirkulasi darah, meningkatkan kekuatan otot betis dan paha, serta mengatasi keterbatasan gerak sendi (Herliawati, 2019). 
Maya Lailasari - Pengaruh Kombinasi Perawatan Luka dan Latihan Range of Motion Ekstermitas Bawah terhadap Penyembuhan Ulkus Diabetik pada Pasien Diabetes Mellitus

Pelaksanaan perawatan luka dan latihan range of motion (ROM) ekstermitas bawah dilakukan kepada subjek studi kasus pada setiap pagi selama 30 menit. Pelaksanaan tindakan perawatan luka dengan menggunakan kompres metronidazole. Setelah perawatan luka selesai, kemudian berikan latihan range of motion (ROM) ekstermitas bawah terutama dengan gerakan dorsofleksi dan plantarfleksi. Hasil ini sama dengan penelitian (Minarningtyas, dkk. 2014) yang menjelaskan bahwa perawatan luka secara konvensional dengan menggunakan $\mathrm{NaCl}$ dan metronidazole yang baik dan benar dapat mempercepat penyembuhan luka kaki diabetik (selama 3 minggu luka membaik) daripada hanya menggunakan $\mathrm{NaCl}$ saja (selama 6 minggu luka baru terjadi pemulihan). Metronidazole merupakan larutan yang fisiologis dengan tubuh sehingga tidak menimbulkan iritasi dan mendukung pertumbuhan granulasi, di samping itu metronidazole merupakan antiseptik sehingga dapat membunuh bakteri dan mempercepat proses penyembuhan luka (Hamil, dkk. 2014)

Hasil penelitian juga disampaikan oleh (Ratnasari, D. 2014) yang menjelaskan bahwa latihan Range Of Motion (ROM) ekstermitas bawah dapat mempengaruhi penyem buhan ulkus diabetik. Saat dilakukan latihan range of motion (ROM) ekstermitas bawah dapat mempengaruhi perfusi perifer yang dapat menyebabkan difusi oksigen dan nutrisi kearea ulkus adekuat sehingga mempengaruhi perbaikan ulkus diabetik. Gangguan pada pembuluh arteri perifer penderita DM dapat mengalami ulkus kaki diabetik yang disebabkan oleh bendungan akibat aliran statis pada vena, dengan dilakukannya range of motion (ROM) pada ekstermitas bawah maka terjadi kontraksi dan relaksasi otot-otot ekstremitas bawah. Gerakan dorsofleksi dengan menggerakkan telapak kaki ke arah tubuh bagian atas sedangkan gerakan plantar fleksi dengan menggerakkan telapak kaki ke arah bawah akan meningkatkan sirkulasi darah ke perifer dan akan mempercepat proses penyembuhan luka karena proses penyembuhan luka salah satunya dipengaruhi oleh sirkulasi yang membawa oksigen dan nutrsi. lancarnya aliran darah ke perifer sangatlah penting khususnya pada pasien ulkus kaki diabetik, karena berhubungan dengan peningkatan proses penyembuhan luka. (Pebrianti, 2018)

Hasil studi kasus menunjukkan bahwa kombinasi perawatan luka dan latihan range of motion (ROM) ekstermitas bawah mampu mempercepat proses penyembuhan ulkus diabetikum. Hasil ini sama dengan penelitian (Mulyono, dkk. 2012) yang menjelaskan bahwa perawatan luka secara konvensional dengan menggunakan $\mathrm{NaCl}$ dan metronidazole yang baik dan benar dapat mempercepat penyembuhan luka kaki diabetik (selama 3 minggu luka membaik) daripada hanya menggunakan $\mathrm{NaCl}$ saja (selama 6 minggu luka baru terjadi pemulihan).

Hasil penelitian senada juga disampaikan oleh (Nugroho, dkk 2018) yang menjelaskan bahwa latihan Range of Motion (ROM) ekstermitas bawah dapat mempengaruhi penyembuhan ulkus diabetik. Saat dilakukan latihan range of motion (ROM) ekstermitas bawah dapat melancarkan sirkulasi sehingga berdampak positif untuk mengurangi timbulnya ulkus dan baik pada proses penyembuhan ulkus diabetik.

Mekanisme perawatan luka dapat mencegah infeksi dan mempercepat penyembuhan ulkus diabetik karena $\mathrm{NaCl}$ 0,9 \% merupakan cairan isotonik dan juga garam fisiologis yang digunakan untuk pembersih, $\mathrm{NaCl}$ 0,9 \% memiliki komposisi dan konsentrasi cairan yang hampir sama dengan cairan tubuh sehingga tidak mengiritasi jaringan, sedangkan larutan metronidazole adalah antibiotik, antibakteri, dan antiprotozoal. Larutan metronidazole dapat melawan infeksi yang 
Maya Lailasari - Pengaruh Kombinasi Perawatan Luka dan Latihan Range of Motion Ekstermitas Bawah terhadap Penyembuhan Ulkus Diabetik pada Pasien Diabetes Mellitus

disebabkan oleh bakteri dan amuba dalam tubuh dan juga metronidazole ini merupakan senyawa nitroimidazole yang memiliki sprektum anti protozoa dan antibacterial yang luas (wijaya, dkk. 2018)

Hasil studi kasus menunjukkan bahwa pasien dilakukan Tindakan ROM pada ekstremitas bawah. Hasil penelitian (Nugroho, dkk 2018) menunjukan bahwa latihan Range Of Motion (ROM) ekstermitas bawah dapat mempengaruhi penyembuhan ulkus diabetik. Penelitian (Purnomo, H. dkk 2019) juga menyampaikan bahwa latihan (ROM) pada ekstermitas bawah merupakan pengobatan utama dalam mencegah dan mempercepat penyembuhan ulkus diabetic.

Saat dilakukan latihan range of motion (ROM) ekstermitas bawah, otot-otot kaki berkontraksi secara terus menerus dan terjadi kompresi pembuluh darah sehingga dapat mengaktifkan pembuluh darah balik. Pembuluh darah balik akan lebih aktif mengalirkan darah ke jantung sehingga sirkulasi darah arteri yang membawa nutrisi dan oksigen ke pembuluh darah perifer menjadi lebih lancar. Aliran darah yang lancar akan memudahkan nutrisi masuk ke sel sehingga dapat memperbaiki fungsi saraf perifer, dan dapat mencegah serta, mempercepat penyembuhan ulkus (Sunaryo, 2014)

\section{SIMPULAN}

Berdasarkan hasil studi kasus yang dilakukan, maka kesimpulan dari penulis adalah terdapat pengaruh kombinasi perawatan luka dan latihan range of motion (ROM) ekstermiatas bawah terhadap penyembuhan ulkus diabetik pada pasien diabetes mellitus. Berdasarkan hasil studi kasus ini diharapkan perawat dapat melaksanakan Tindakan perawatan luka dan ROM pada pasien diabetes melitus yang mengalami ulkus diabetikum untuk mengoptimalkan proses penyembuhan luka.

\section{UCAPAN TERIMA KASIH}

Terima kasih penulis ucapkan kepada semua pasien yang telah bersedia menjadi subjek studi kasus, terima kasih ucapkan kepada pembimbing, penguji dan rekanrekan sejawat yang telah membantu dalam penyelesaian karya tulis ilmiah ini, dan semua pihak yang telah membantu dalam pelaksanaan tugas akhir sehingga dapat terselesaikan sesuai dengan target waktu.

\section{REFERENSI}

Hamil, Y. I., Setya, D., \& Nugrahani, F. (2014). Efektivitas Kompres Metronidazole Dengan Kompres Providon Iodin Pada Penyembuhan Luka Diabetes Mellitus Tipe 2. Jurnal Keperawatan Indonesia. https://scholar.google.co.id/scholar?q=relate d:_qWpm2mhBL4J:scholar.google.com/\&scioq

Herliawati. (2019). Sensivitas Kaki Penderita Diabetes Mellitus Antara Dua Perlakuan. Jurnal Keperawatan

Sriwijaya.https://ejournal.unsri.ac.id/index.p hp/jk_sriwijaya/article/view/7651/3841

Minarningtyas, A., \& Tami, A. M. A. (2018). Perawatan Luka Konvensional Dan Modern. Jurnal Gema Keperawatan. http://ejournal.poltekkesdenpasar.ac.id/index.php/JGK/article/view/6 36

Mulyono, E., \& Adi, G. S. (2012). Pengaruh Kompres Metronidazole Terhadap Luka Kaki Diabetikum. Jurnal kesehatan kusuma husada. http://jurnal. ukh.ac.id/index.php/JK/article/view/29

Nugroho, S. H. P., \& Puspitasari, D. (2018). Range of Motion (ROM) Angkle Untuk Mempercepat Penyembuhan Luka Ulkus Kaki Diabetik Berdasarkan Karakteristik Warna Luka. Unisula Nursing Conference Call For Paper \& National Conference.http://lppmunissula.com/jurnal.unissula.ac.id/index.php/ unc/article/view/2901

Nurarif, A. H \& Kusuma, H. (2015). Aplikasi Asuhan Keperawatan Berdasarkan Diagnosa Medis Dan Nanda Nic- Noc. Edisi Revisi Jilid 1. Jogjakarta:Medication Jogja

Pebrianti, S. (2018). Buerger Allen Exercise Dan Ankle Brachial Index (Abi) Pada Pasien Ulkus Kaki Diabetik. Indonesian Journal of nursing sciences \& practice. https://jurnal.umj.ac.id/index.php/ijnsp/artic 
Maya Lailasari - Pengaruh Kombinasi Perawatan Luka dan Latihan Range of Motion Ekstermitas Bawah terhadap Penyembuhan Ulkus Diabetik pada Pasien Diabetes Mellitus

le/view/2710/2323

Purnomo, H., Mu'awanah., Mudhofar, M. N., Normawati, A. T., \& Suprasno, L. (2019). Pengaruh Latihan Peregangan Kaki Terhadap Pengisian Kapiler Pada Penderita Luka Ulkus Diabetes. Jurnal Studi Keperawatan. Http://Ejournal.PoltekkesSmg.Ac.Id/Ojs/Inde x.Php/JSikep/Article/View/6353

Ratnasari, D. (2014). Pengaruh Latihan Range of Motion ( ROM) Ekstermitas Bawah Terhadap Perbaikan Ulkus Diabetic Pada Pasien Diabetes Mellitus Tipe 2. Jurnal Medika Cendekia. https://scholar.google.co.id/scholar?hl=id\&as _sdt $=0 \% 2 \mathrm{C} 5 \& \mathrm{q}$

Smeltzer, C. (2013). Buku Ajar Keperawatan Medikal Bedah, Edisi 12. Jakarta: EGC.

Sunaryo, T., \& Sudiro, S. (2014). Pengaruh Senam Diabetik Terhadap Penurunan Resiko Ulkus Diabetik Pada Pasien DM. Jurnal Ilmu Kesehatan. http://jurnal.poltekkessolo.ac.id/index.php/Int/article/view/81
Tim Pokja SDKI DPP PPNI. 2016. Standar Diagnosa Keperawatan Indonesia. Jakarta :Dewan Pengurus Pusat Persatuan Perawat Nasional Indonesia

Wijaya, A. S., \& Putri,Y. M. (2013). Keperawatan Medikal Bedah Cetakan Pertama. Yogyakarta: Nuha Medika

Wijaya, N. I. M. S., \& Kep, M. (2018). Perawatan Luka Dengan Pendekatan Multidisiplin. Yogyakarta: Andi

Cho, N. H., Kirigia, J., Claud, J., Ogurstova, K., Guariguata, L., Rathmann, W. Roglic,G., Forouhi, N., Dajani, R., Esteghamati, A., Boyko, A., Hambleton., Neto O. L., Montoya, P., Joshi,S., Chan, J., Shaw, J. Samuels, T., \& Pavkov, M. (2017). Internatinal Diabetes Federation Diabetes Atlas, Eighth Edition. Online version of IDF Diabetes Atlas:www.diabetesatlas.org 